\title{
A Framework for Continuous Improvement in Supply Chain Management Education
}

\author{
Kaitie Perrine, Sime Curkovic \\ Center for Integrated Supply Management, Haworth College of Business, Western Michigan University, Kalamazoo, MI, USA \\ Email: kaitlyn.n.perrine@wmich.edu, sime.curkovic@wmich.edu
}

How to cite this paper: Perrine, K., \& Curkovic, S. (2022). A Framework for Continuous Improvement in Supply Chain Management Education. Creative Education, 13, 466-483.

https://doi.org/10.4236/ce.2022.132027

Received: December 19, 2021

Accepted: February 13, 2022

Published: February 16, 2022

Copyright $\odot 2022$ by author(s) and Scientific Research Publishing Inc. This work is licensed under the Creative Commons Attribution International License (CC BY 4.0).

http://creativecommons.org/licenses/by/4.0/

(c) (i) Open Access

\begin{abstract}
As the industry of supply chain recovers from surging demand, educational elements that prepare graduates to successfully enter and sustain positions in management are more valuable than ever. The evolution of the supply chain continues to introduce new ways to improve purchasing, logistics, and production, which are all essential aspects in Integrated Supply Management and the education associated to prepare graduates. Promoting live experimentation using the universally accepted framework for continuous improvement, known as the A3 process, allows leaders in education to emphasize the importance on the contributing qualities to supply management. Student reports and presentations translate the grasp on fundamental concepts from the classroom and practices application with projects designed within successful organizations. It is shown from the research at Western Michigan University that graduates are more prepared to meet the success standard that employers are looking for by gaining real-world experience in one of the required management courses within the carefully designed curriculum. This paper reflects on how qualities associated with continuous improvement education sync to the current business needs of the industry and describes the hands-on experimentation process that all Western Michigan University Integrated Supply Management majors must complete to gain the industry experience that is required to be job ready upon graduation.
\end{abstract}

\section{Keywords}

Supply Chain Management, Problem-Solving, Experimental Learning, Lean Six Sigma, Quality Assurance and Control

\section{Introduction}

It is no secret that today's society is more familiar with supply chain manage- 
ment than they used to be. Ted Prince, COO of logistics servicer Tiger Cool Express, makes the case for the Oxford University Press in establishing "supply chain" as a word of the year in 2021 (Prince, 2020). The popularity of the word came from households watching companies struggling to keep up with COVID-19's influence on a surging demand from the public. Manufacturers around the globe replenished product and recovered with an exceptional projected growth for its future. The industry of Supply Chain Management (SCM) is forecasted to expand at a compounding annual growth rate of $17.3 \%$ until 2028 (Grand View Research, 2021). In the manufacturing world, the most recent ISM Manufacturing Index registered at $59.9 \%$ indicating the expansion of U.S. economic activity in this sector (Institute for Supply Management, 2021). This information is crucial for existing members of SCM as the already apparent talent shortage is expected to increase if positions are not filled.

The available positions in the supply chain field are left open by the Baby Boomer generation that is quickly reaching retirement. There is a clear correlation between the conditions of the pandemic and increased retirement rates from those born between 1946-1964. Over 3 million more Boomers reported retirement or exiting the work force in 2020 than the last year (Fry, 2020). According to the Bureau of Labor Statistics, the shift of the Boomer generation to older age will influence the labor force participation rate to continue its decline over the next 10 years (U.S. Bureau of Labor Statistics, 2013). With this fall, the demand for workers greatly exceeds its supply. It is up to leaders and managers to retain and recruit those with skill sets that are up to the industry's standards.

Both tactical and operational expertise, as well as analytical skills, are sought after by employers in the SCM field, but $58 \%$ of companies say this combination is hard to find (Apple, 2021). Concerned about their competitive advantage, companies are sharpening their creation and sustenance of a successful supply chain. Logistics, purchasing, and planning are becoming incredible areas of focus for organizations that are looking to evolve their supply chain to keep up with the competition in the industry. Specific improvement efforts in these areas are tackled by SCM leaders to do things better than others, faster than others, and with a cost savings benefit to ultimately provide that competitive edge every business wishes to achieve. These same ideas are reflected in a statement from Sleek Technologies earlier this year: "What remains constant in any company that has a supply chain advantage is that the supply chain is fully optimized and has the ability to deliver goods faster and cheaper than the competition." (Technologies, 2021) Western Michigan University's (WMU) Integrated Supply Management (ISM) program recognizes this as the University holds an importance on the continuous improvement opportunities that appear throughout the logistics, purchasing, and planning of SCM.

Students enrolled in ISM courses at WMU are taking advantage of a nationally ranked supply chain program according to The Gartner Report-a national researcher on top U.S. supply chain undergraduate programs. With a rank of 
$11^{\text {th }}$ nationally in 2020 , the development of skills in students throughout their educational career at WMU is some of the best available in the nation (Chumakov \& Stiffler, 2020). Top tier talent is a response to a curriculum that combines engineering, logistics, supply chain, business education, and hands-on experience that are required for graduates to prepare for solving challenges in the supply chain field. In 2017, WMU was ranked the $2^{\text {nd }}$ best ISM program for producing talent by SCM World, a cross-industry community powered by the world's most influential supply chain practitioners (Watson, 2017). Just before this, in 2015, the WMU ISM program was again ranked number 2 in the nation by Software Advice, a Texas-based resource company for software buyers that awarded the University on instructing courses with various technology and software exposure required for graduation from the program. Software Advice was acquired by Gartner in 2014, placing an irrefutable credibility on their minds in research (Jones, 2019; Gartner, n.d.). Worldwide supply chain leaders have recognized the talent that emerges with WMU graduates and national recognition helps build a powerful reputation. This paper reflects on the characteristics of a WMU supply chain graduate that are credited to the current business needs of the industry and the framework for continuous improvement used in every SCM job for solving problems.

\section{The Preparedness Gap}

There is both a financial and mental investment that a student maintains throughout their educational career. The success in the student's study and practice prepares them for meeting workforce expectations and builds a confidence in their personal brand. Placing a high priority on this success is important and overall, benefits the student's life in both personal and professional aspects.

The Association of American College and University (AAC\&U) conducted a survey in October of 2020 labeled "How College Contributes to Workforce Success: Employer Views on What Matters Most," which provides insight into performance evaluations on recent graduates by nearly 500 top executives and hiring managers. Assessing recent college graduates' preparedness levels on factors deemed essential for success revealed a noticeable gap between how important the factor is and how many are prepared to successfully perform at that level. Table 1 shows the important skills and the gap evaluated by the study. The largest gap is in critical thinking skills, followed by application of knowledge/skills in real-world settings, with the third largest gap at $16 \%$ in working effectively in teams (Flaherty, 2021).

It is important for the reputation of a college degree that these gaps be closed. A recent study conducted by the Society for Human Resource Management with the Pew Research Center of roughly 1400 educational professionals, produced findings of the top missing skills of graduates being critical thinking, communication, and the ability to deal with complexity and ambiguity (Wilkie, 2020). The similarities in the data produced by both surveys influences those working 
Table 1. The AAC\&U survey results on essential skills.

\begin{tabular}{|c|c|c|}
\hline & $\begin{array}{ll}\text { Share of } & \text { Share of employers who } \\
\text { employers who } & \text { report that recent graduates } \\
\text { deem a skill to be } & \text { are "very well prepared" on } \\
\text { "very important" } & \text { a particular skill }\end{array}$ & $\begin{array}{l}\text { Preparedness } \\
\text { Gap }\end{array}$ \\
\hline Work effectively in teams & $62 \% — 48 \%$ & $14 \%$ \\
\hline Critical thinking skills & $60 \% \_39 \%$ & $21 \%$ \\
\hline Analyze and interpret data & $57 \% \longleftarrow 41 \%$ & $16 \%$ \\
\hline Application of knowledge/skills in real-world settings & 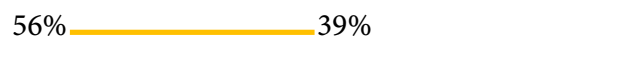 & $17 \%$ \\
\hline Digital literacy & $55 \% \_49 \%$ & $6 \%$ \\
\hline Communicate effectively through writing & $54 \% \longleftarrow 44 \%$ & $10 \%$ \\
\hline Ethical judgement and reasoning & 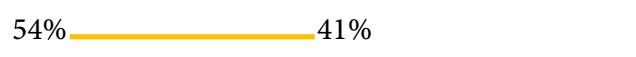 & $13 \%$ \\
\hline Demonstrate complex problem-solving skills & 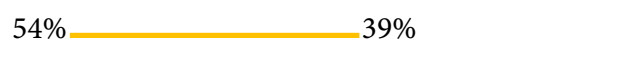 & $15 \%$ \\
\hline Communicate/work with people from different cultural backgrounds & $54 \% \longleftarrow 43 \%$ & $10 \%$ \\
\hline Locate, evaluate, and use information in decision making & $53 \% \longleftarrow 42 \%$ & $11 \%$ \\
\hline Creative thinking & $53 \% \longleftarrow 46 \%$ & $7 \%$ \\
\hline Communicate effectively through speaking/presentation skills & $52 \% \_41 \%$ & $11 \%$ \\
\hline Work with numbers and statistics & 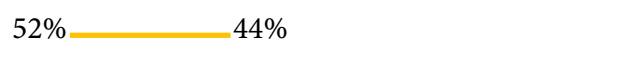 & $8 \%$ \\
\hline Integrate ideas/information across different settings and contexts & $51 \% \longleftarrow 39 \%$ & $12 \%$ \\
\hline Civic skills/civic engagement & $41 \% \_44 \%$ & $3 \%$ \\
\hline
\end{tabular}

towards a college degree to determine how vital it is for their professional career to attend universities that incorporate solutions for preparedness in the workforce. Many universities are putting an emphasis on closing the preparedness gap with recognition from the president of the AAC\&U stating that the "education fosters the adaptability and flexibility necessary to apply skills in a variety of contexts and respond to a rapidly changing world." (Flaherty, 2021) Based on research and observation of the job market, the student can see value in practicing problem solving and application of critical thinking during their higher education.

\section{The Industry}

Special attention is paid to the course work that is pushed onto students from the college or university they attend. Employers are after the missing talent that provides the competitive edge in business. The American Management Association (AMA) encourages university curriculums to focus on "the four C's" to shape a successful employee. The AMA Critical Skills Survey defines the four C's as the following:

1) Critical thinking/problem solving-the ability to make decisions and act as appropriate.

2) Communication - the ability to synthesize and transmit your ideas both in written and oral forms. 
3) Collaboration and team building - the ability to work effectively with others, including those from diverse groups and opposing points of view.

4) Creativity and innovation-the ability to see what is NOT there and make something happen.

These are the skills that over 2000 managers and executives say they measure and evaluate their employees' on in annual performances and mastering these provides a substantial advantage to job applicants (AMA Staff, 2019). It is important to note that the business industry is never stagnant, and each critical skill is useful in its adaptability to different scenarios.

Breaking down the skills, critical thinking shows up time and time again in multiple studies on missing or crucial talents in the industry. Critical thinking is universal, dire for the economy, and improves presentation skills for those that use it. The ability to make decisions promotes creativity and is incredible for self-reflection with justification on the ways we choose to live life. Communication is a life skill that can constantly be improved, but only $38.1 \%$ of the executives surveyed by the AMA say their employees are above average in this crucial area. Above average communication is part of the foundation for worker productivity and employee job satisfaction, which ultimately lowers an organization's job turnover rate. Working in teams and being a collaborative member weighs heavy on the idea that networking and globalization of business is vital for success. Collaboration broadens the practice of communication that allows teams to set goals, discover talents from the other members, all while building a cohesive and inclusive environment amongst employees. This projects onto the fourth critical skill of creativity by fostering an environment that is non-judgmental of everything diverse. According to the AMA, only $37.4 \%$ of companies say their employees are above average in creativity and innovation. Being able to combine critical skills to make something happen with no direct instruction describes the creative or innovative individual desired for this industry. Intrinsic rewards are emphasized in the workplace to best practice motivation for creative innovation. Challenging employees, opportunities for advancement, empowerment in leadership, and participation in important decision making encourages the independent progression in this critical skillset (AMA Staff, 2019; Business Performance, 2014; Field, 2012; Hicks Terry, 2015; Panigrahy \& Kumar Pradhan, 2015; University of the People, 2021).

Available information on industry success does not get by without notice from Western Michigan University's AACSB accredited Haworth College of Business. Preparing students to recognize and adapt to lifelike situations transforms the classroom into a hands-on practice that leads to experience in continuous improvement and engagement with the local business community.

\section{Western Michigan University's Integrated Supply Management Program}

Input on how to enter the industry successfully from thousands of professionals 
in SCM clarifies the significant skills in the ideal employee (i.e., critical thinking, teamwork, problem-solving, etc.). Western Michigan University exposes their ISM graduates to several required courses that cover the practical and tactical way of figuring and adapting solutions to an industry filled with problems to solve and processes to improve. Through an intense curriculum to prepare the student for their profession, WMU emphasizes the importance of broadening their average skill set. This closes the preparedness gap in several categories between employers and WMU graduates; providing the competitive advantage every company seeks in new hires.

WMU puts a strong focus on the engineering component of supply chain. Understanding the initial processes of production is critical to keeping up with the industry demand and expectations. Engineering specific courses required for ISM graduates such as Engineering Graphics and Quality Assurance and Control provide students the opportunity to fully consider all parts of the supply chain and identify areas of improvement. Within these courses, the heavy manufacturing exposure in techniques and applications creates value in building backgrounds in engineering and manufacturing. This has been appreciated by local and international companies that consistently recruit from WMU's ISM program like Stryker, Parker Hannifin, Honda, Whirlpool, and General Motors (Table 2).

Additionally, ISM students cover a variety of general business courses that develop the critical thinking, communication, collaboration, and creativity component needed in the real world. Courses like Managing ERP Systems, Supply Chain Logistics, Production Management and Control, and Applied Six-Sigma Problem-Solving provide a well-rounded talent that impacts many segments of the supply chain. This area of study proposes a broad spectrum of specialties and employment opportunities for graduates to consider, as the ISM program prepares students to accept positions that range from the procurement of raw materials to managing and overseeing operations throughout all organizations. Table 1 provides various job titles received by WMU graduates that have completed the ISM program.

Working hands-on with technology and physical processes prepares a confidence in performing in several areas-giving Western students the ability to bring value in skills beyond "the four C's". The management and experimental course projects turn knowledge into an applicable asset to the employer. As technology advances, employers take special consideration for those who are skilled in Microsoft Office Applications like Excel and Access, as well as those who are familiar with Power BI, Tableau, CAD, and ERP systems like SAP which have been built into the curriculum for WMU students. Given that Western Michigan's ISM program requires 43 credits, (Penn State University has the next highest ISM credit requirement at 24 credit hours) there is an obvious competitive advantage that these graduates have when it comes to preparedness and exposure.

Table 3 lays out the required courses for WMU ISM graduates. It is incredibly 
Table 2. Median Salary for WMU ISM Graduates in 2019: $\$ 62,000$.

Job Titles

Employers that Recruit WMU's ISM

Graduates
Account Manager, Buyer, Commodity Manager, Supply Chain/Logistics Analyst, Production Manager, Production Scheduler, Project Manager, Purchasing Analyst, Sourcing Specialist, Supply Chain Engineer, Systems Analyst, Logistics Coordinator, Supply Chain/SAP Coordinator, Operations Supervisor, Inventory Manager, Warehouse Manager

Amazon, Bronson Healthcare, Coca-Cola, Eaton, Ford Motor Company, General Motors, Haworth Inc., Honda, IBM, J.B. Hunt, John Deere, Kellogg's, Kraft Heinz, Marathon Petroleum, Perrigo, Rolls Royce North America, Stryker, Target, Total Quality Logistics, Texas Instruments, Werner Enterprises, and Whirlpool

Table 3. WMU's Required Credits for ISM Graduates: 43.

\begin{tabular}{ll}
\hline $\begin{array}{l}\text { Management (12 } \\
\text { Credits) }\end{array}$ & MGMT 2800-Intro to Supply Management, \\
& MGMT 3200-Managing ERP Systems, \\
& MGMT 3810-Applied Six Sigma Problem Solving, and \\
& MGMT 4640-Production Management and Control \\
Marketing (6 Credits) & MKTG 3720-Sourcing and Purchasing, and \\
& MKTG 4630-Supply Chain Logistics, \\
Engineering (16 & EDMM 1420-Engineering Graphics, \\
Credits) & EDMM 1500-Intro to Manufacturing, \\
& EDMM 1501-Processes and Materials in Manufacturing, and \\
& EDMM 3280-Quality Assurance and Control, \\
Law (3 Credits) & LAW 4840-International Business Law or \\
& LAW 4860-Marketing and Sales Law \\
Supply Chain Electives & GEOG 3010-Fundamentals of Geographics Info Systems, or \\
(6 Credits) & EDMM 4870-Manufacturing Productivity Techniques, or \\
& EM 5120-Management of Service Operations with \\
& MKTG 4880/EDMM 4880-Applied Process Reengineering
\end{tabular}

common for these graduates to obtain a minor in business analytics, allowing consideration in various careers with data analysis, data mining, or data management. Many students are encouraged to participate in global negotiation, a course designed to familiarize the student with opportunities to increase benefits and salary offers from employers. All courses combined, the skills and experiences that WMU trains their graduates on are highly sought after by employers. The supply chain industry is more valuable when employees are skilled in areas of continuous advancement. Careers in technology, analytics, marketing, and finance are available to ISM majors as these areas complement an organization's supply chain and WMU students prepare specifically for versatility and adaptability in the workforce.

The national median salary for SCM professionals holding a bachelor's degree is $\$ 78,750$ according to the 2020 Association of Supply Chain Management 
(ASCM) salary report (Talbert, 2020). WMU graduates entering the SCM field are reporting back a $95 \%$ actively engaged status and $96 \%$ of respondents are in careers directly related to their degree. The post-graduation activity report from 2019-2020 provides feedback on how internships and course projects required by their program play a part in the preparedness for employment that has ultimately led to graduates submitting nearly $90 \%$ in related job satisfaction (Urban \& Miller, 2021). The combination of strong financial reputation and overall wellness of those working in supply chain is an attractive element to credit the industry projected to grow so consistently over the next several years.

\section{Management 3810-Applied Six Sigma Problem-Solving}

Based off the research done by Sroufe and Ramos published in the Decision Sciences Journal of Innovative Education, live projects are an evidential credit to the preparedness and overall success of graduates entering employment (Sroufe \& Ramos, 2011). It is this study that the progression of WMU's Management 3810 course is influenced. Versatility in problem solving is one of the most attractive attributes to employers and through live experimentation, the influence that lean management has on the supply chain is essential. A driving force behind WMU's ISM program success is the ability to seek out the variables associated with doing things better, faster, and cheaper in a hands-on, practical way. By incorporating a non-traditional approach to the curriculum, these ISM students are more prepared to tackle a variety of challenges faced in supply chain by applying a framework to continuously improve functional elements.

Contributing to the evolution of supply management theory and practice through scholarly teaching, discovery, integration, and application is the mission of the WMU ISM program. This alignment in long-term goals for the graduate matures through practices such as the Applied Six Sigma Problem-Solving course (MGMT 3810), which provides opportunities for students to grow talents and problem-solve in a way that is effective and realistic. Management 3810 is offered to ISM students halfway through their degree requirements, as a foundation of supply chain industry knowledge is needed before project goals can be fully optimized and understood. After mastering concepts and techniques of process management, students enrolled in MGMT 3810 practice applying that knowledge to an on-site industry process in a semester long project. Success in this course builds on current industry needs, which produces a competitive advantage within WMU graduates. The specific mission of the course is for each student to authenticate best practices of SCM while developing the professional skills required for managing people, processes, and resources.

Faculty associated with the ISM program at WMU work closely with local businesses and their leaders to design projects in lean management for students to solve during their course project. Backgrounds for different solutions presented within the course include the A3 structured approach, the Single Minute Exchange of Die (SMED) system, value stream mapping strategies, Lean Six-Sigma, 
and the 5S's. These backgrounds provide countless ways for innovation in problem-solving and they allow students the ability to organize and execute various improvement strategies. The focus of the project presented in this course revolves around major functions of the supply chain within local organizations and placing those areas under inspection and evaluation by terms instilled within a framework of continuous improvement known as the A3 problem-solving process.

Students enrolled in this course are assembled into teams, where they prepare to work with leaders and directors from companies like Stryker, Bronson Hospital, Mann-Hummel, Senneca, Parker Hannifin, Kellogg, and Whirlpool to obtain valuable, professional work experience that is unique to a student's semester workload. This collaboration among students and leaders in process improvement builds on confidence in decision making, which is essential for any management position in supply chain. The preparedness to successfully execute ideas and to do so with a group in a real-world setting is a product of completing Management 3810.

Building on SCM concepts and techniques that these upperclassmen have learned in past courses, MGMT 3810 students learn in heavier detail about the functions of a firm's supply chain strategy, their operations, and the related principles. This course is intended to provide students with an understanding of the design, implementation, and management aspects of effective and efficient integrated supply chain systems by solving real industry issues specifically using the A3 process. This class has sponsored over 200 industry projects since its conception (2008), which translates into millions of dollars saved for these partners, as well as improved competitive functions of their supply chains in quality, service, and flexibility.

\subsection{Course Description}

Taught as a seminar for sharing learning, best practices and knowledge across teams and clients, the course requires all students to examine issues beyond their project scope and client concerns. Students work in teams to frame problems, develop solution paths, and manage projects from conception to completion for an assigned client or company. The focus is on improving processes, inspiring innovation, and creating competitive advantages-both short and long term for real world organizations. Client deliverables include a formal presentation to the client management team that will lead to productivity gains, cost savings, revenue increases, and profit growth when implemented by the client. Note, some students are able to implement their recommendation if time permits within their four-month semester, but all student groups are required to make an implementation plan at the bare minimum. There are also occasions of client companies having the projects evolve from one semester to the next where the new project is building off the last for additional value to the client. Students function as professional consultants, working closely with a client organization 
to analyze internal/external situations, drivers, and risks; to identify problems and opportunities; to evaluate return on investment from alternative courses of action; and to recommend solutions for short- and long-term prosperity. Students apply proven models and methodologies and hone their skills as a project manager, researcher, analyst, writer, speaker, and peer coach.

\subsection{Alignment with Undergraduate Program Goals}

Building on other foundational courses in the business college, students apply more advanced concepts and models from marketing, finance, accounting, operations, law, human resources, economics, statistics, information technology, and their signature supply chain courses. Students will develop and test hypotheses; conduct primary and secondary research; collect and analyze data; establish goals and metrics and action plans; and prepare persuasive proposals and presentations. The project work provides exposure to organizations as holistic systems where students communicate across organizational levels, functional disciplines, and cultures in practical workplace situations. The course goes beyond academic case studies and simulations; it offers a professional proving ground for demonstrating that students can apply their graduate education, manage people and processes, and provide innovative, feasible solutions to improve an organization's bottom line.

\subsection{Course Pedagogy}

Serving as consultants with external clients, you will be representing Western Michigan University, the ISM program, and the Haworth College of Business. Their clients are looking for bold new ideas for improving competitiveness and profitability. They expect rigorous analysis, both quantitative and qualitative, that reflects the breadth and depth of an accredited, globally recognized curriculum. The student's clients have prepared a preliminary project description, but the team must refine and articulate project goals, scope, tasks, timetables, and deliverables. WMU faculty encourage the students to bring curiosity, creativity, and enthusiasm to uncovering opportunities.

The course instructors function as senior partners and risk managers for the student team's consulting engagement, providing overall direction, including standardized templates, tools, and protocols to assure quality control throughout. The instructors preview all documents and presentations before they are shared with the client organizations to ensure sound reasoning and professionalism. This screening process will limit risk for the students and the university during the learning process. The course schedule lists formal checkpoints and status reviews, but instructors are also available for informal coaching, and you will have access to the expertise of professionals throughout WMU's educational community.

\section{A3 Problem Solving}

The A3 process is a framework tool for lean management that originated with 
Toyota automotive and the common practice of using the A3 sized paper, $11^{*}$ 17 inches (Figure 1), to tell tales of quality improvement within Japanese organizations. Toyota manufacturers, managers, and engineers are known for using the A3 continuous improvement technique to result in high quality products that are recognized throughout the globe. The auto-industry readily adopted this successful framework as a means to stay in competition with Toyota. Today, the A3 process can be found in most organizational functional improvement strategies from procurement to distribution, including the companies that team up with WMU's MGMT 3810 course.

The A3 process is a ten-step approach (Table 4) designed to target specific problems within a firm, while maintaining an objective to eliminate recurrence of the respective issue. The A3 diagram is designed to keep presentation and thought processes simple (Rubrich, 2010). This helps students articulate the necessary information to move forward in solving any problem faced in the industry. It is known as the framework for continuous improvement as ultimately any issue can be figured through this process to define measurable deliverables that positively influence the direction of an organization's supply chain.

This practice is essential for graduates to gain experience. Problem-solving techniques heavily impact a student's resume and MGMT 3810 is specifically preparing students to perform at a successful rate once they are hired. It is within the first steps of the A3 framework that challenges students to think about the root cause or causes of identified problems, which stimulates the creative innovation that every company searches for. The companies that have used WMU's

THEME: "What are we trying to do?"

\begin{tabular}{|l|}
\hline Background \\
\hline$\cdot$ Background of the problem \\
- Context required for full understanding \\
- Importance of the problem \\
\hline
\end{tabular}

\begin{tabular}{|l|}
\hline Target Condition \\
\hline$\cdot$ Diagram of proposed new process \\
$\cdot$ Countermeasures noted as fluffy clouds \\
$\cdot$ Measurable targets (quantity, time) \\
\hline
\end{tabular}

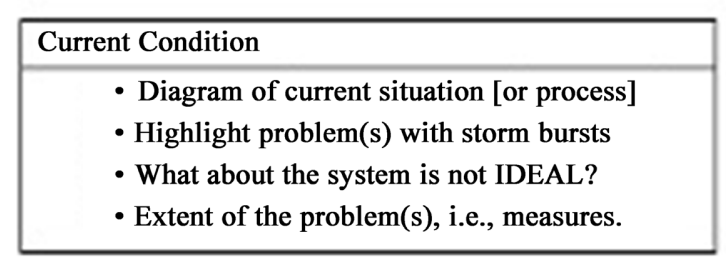

\begin{tabular}{|c|c|c|c|}
\hline \multicolumn{4}{|l|}{ Implementation Plan } \\
\hline What? & Who? & When? & Where? \\
\hline $\begin{array}{c}\text { Actions to } \\
\text { be taken }\end{array}$ & $\begin{array}{c}\text { Responsible } \\
\text { person }\end{array}$ & $\begin{array}{c}\text { Times and } \\
\text { dates }\end{array}$ & $\begin{array}{c}\text { Locations for } \\
\text { the actions }\end{array}$ \\
\hline Cost: \\
\hline
\end{tabular}

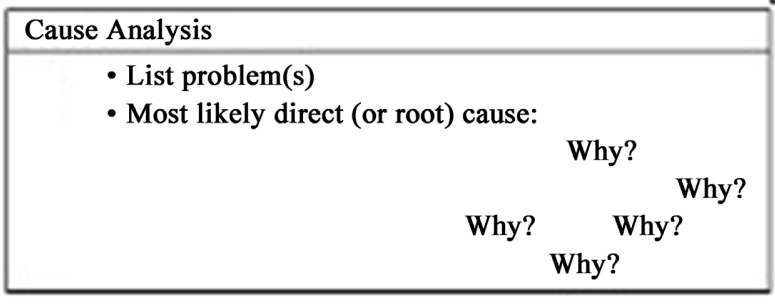

\begin{tabular}{|c|l|}
\hline \multicolumn{1}{|l|}{ Follow-Up } \\
\hline \multicolumn{1}{|c|}{ Plan } & \multicolumn{1}{c|}{ Actual results } \\
\hline - How will you check & ・ In red ink/pencil \\
the effects? & • Date check done \\
$\bullet$ When will you check & $\bullet$ Results compared to predicted \\
\hline them? & \\
\hline
\end{tabular}

Figure 1. The A3 diagram. 
Table 4. A3 Process steps.

\begin{tabular}{|c|c|c|}
\hline Step & Theme & Description \\
\hline Step 0: & Identify Problem or Need & $\begin{array}{l}\text { - Background knowledge of problem } \\
\text { - Context for full understanding } \\
\text { - Level of importance of problem }\end{array}$ \\
\hline Step 1: & $\begin{array}{l}\text { Understand the Current } \\
\text { Situation }\end{array}$ & $\begin{array}{l}\text { - Observe work processes first-hand } \\
\text { - Document observations } \\
\text { - Diagram how the work is currently done } \\
\text { - Quantify magnitude of the problem }\end{array}$ \\
\hline Step 2: & Root Cause Analysis & $\begin{array}{l}\text { - List the problem(s) } \\
\text { - Most likely direct (root) cause } \\
\text { - Five why process }\end{array}$ \\
\hline Step 3: & Countermeasures & $\begin{array}{l}\text { - Identify changes needed } \\
\text { - Eliminate loops, workarounds, and delays } \\
\text { - Create clear connections to solutions }\end{array}$ \\
\hline Step 4: & Develop the Target State & $\begin{array}{l}\text { - How work will get done after applying countermeasures } \\
\text { - Diagram created to illustrate new proposed process } \\
\text { - Expected improvement should be predicted specifically and quantitatively }\end{array}$ \\
\hline Step 5: & Implementation Plan & $\begin{array}{l}\text { - List the actions needed to put in place countermeasures } \\
\text { - List individuals responsible for each task } \\
\text { - Due dates put in place }\end{array}$ \\
\hline Step 6: & Follow-up Plan & $\begin{array}{l}\text { - Verify the understanding of current condition } \\
\text { - Make sure implementation plan was executed, target condition realized, and the } \\
\text { expected results are achieved }\end{array}$ \\
\hline Step 7: & $\begin{array}{l}\text { Discuss with All Affected } \\
\text { Parties }\end{array}$ & $\begin{array}{l}\text { - Communicate with all partied affected by the implementation } \\
\text { - Build consensus throughout the project }\end{array}$ \\
\hline Step 8: & Get Approval & - Obtain approval from the correct authority figure \\
\hline Step 9: & Implementation & - Execute the implementation plan as prepared \\
\hline Step 10: & Evaluate the Results & $\begin{array}{l}\text { - Measure the actual results } \\
\text { - Compare results to the predicted outcomes } \\
\text { - When differences are present, modify the process and repeat the implementation until } \\
\text { the goal is met }\end{array}$ \\
\hline
\end{tabular}

Applied Six Sigma course as a form of teaching experiment have first-hand knowledge of the benefits associated with this instruction. Not only are the supply chain processes better off, but the networking involved between students and the leaders of these largely successful, globally influential companies, brings a level of confidence not found among other graduates. It is this preparedness that entices companies to recruit WMU graduates as the competitive advantages be- 
come apparent with required, hands-on experience in problem-solving.

\section{The Process Improvement Project Phases}

Once the student teams for the semester are arranged, a kick-off meeting with the assigned members is initiated. Assignment is related to remote/in-person projects, prior networking, or a combination of both. Operations directors, supervisors, and associates of the partnered organizations are involved in the kick-off meeting to ensure the project scopes are completely defined. A few project topics are determined by these leaders, allowing the students to choose from areas that interest them personally. The processes chosen are not to be undergoing any form of improvement already, and the students must be able to have access to the actual process where they can gather data from.

Each group will submit a description of at least one of the processes they've chosen to evaluate (1/2-1 page each). The following step is to complete the project proposal. The problem-solving begins with identification of what the teams will need to ensure clear communication throughout the semester and the project proposal will do just that by identifying: a project title, a "Company Project Champion" from the hosting organization, a clearly defined project scope, the specific and measurable project deliverables, and the background information relating to the process as well as the company. It is essential that each team prepare this proposal before they begin the A3 process so that the faculty associated can be confident in the deliverables for the hosting organization to be satisfied.

With input from the instructor, the teams analyze the selected process. Examples from previous students include (examples can be found in Table 5):

- Medical record completion process

- A warranty claim process

- The process of assembling, preparing, and packing components for shipment

- The receiving process at a major hospital

Table 5. Company projects.

\begin{tabular}{|c|c|}
\hline Project & Description \\
\hline $\begin{array}{l}\text { Applying Lean } \\
\text { Manufacturing } \\
\text { Practices }\end{array}$ & $\begin{array}{l}\text { Part consolidation to improve Company A's use of production floor space. The students collected data on } \\
\text { parts by weight, location, and container, then proposed solutions to reduce inventory and implement a JIT } \\
\text { system for the production floor. }\end{array}$ \\
\hline $\begin{array}{l}\text { The Supermarket } \\
\text { Project }\end{array}$ & $\begin{array}{l}\text { ISM students assigned to Company A's warehouse for a major product division. Students took inventory of } \\
\text { parts used, size and weight, standardized shipment packaging and holding bins, and implemented } \\
\text { improvements for circulation of parts. }\end{array}$ \\
\hline $\begin{array}{l}\text { Indirect Supply } \\
\text { Consolidation }\end{array}$ & $\begin{array}{l}\text { The group formulated short- and long-term goals that included creating procedures for proper oversight of } \\
\text { the indirect supply base, setting buyer authorization levels, creating a scorecard to evaluate indirect suppliers, } \\
\text { suggesting up-to-date ERP systems and e-tools, creating a preferred list, using strategic purchasing methods. }\end{array}$ \\
\hline Kanban Project & $\begin{array}{l}\text { Company A's product line team leaders worked with a group of ISM students to effectively change the } \\
\text { Kanban sizes and reorder point quantities of all the parts on an integral product line. }\end{array}$ \\
\hline
\end{tabular}




\subsection{Group Presentations}

Throughout the semester, each team is required to present their findings from each step of the A3 framework. Presenting each step to the instructor provides the practice for students to include material that is specific and efficient in problem-solving. The submissions throughout the semester of each completed step also open the door for the instructor to provide positive feedback or criticize constructively with realignment of the deliverables in association with the project goals. (Table 4) These initial steps give way to a communication channel used between the student and instructor all semester long for discussions in problem areas and where/how improvements are expected to be made. In the initial stages of the project, it is not unlikely that the host company requires the students to sign a non-disclosure agreement.

A final presentation is required by each team, and is typically given at the host company, or around the host company's schedule in an online video room such as Zoom, Microsoft Teams, or WebEx. The flexibility continues to evolve in a world recovering from a pandemic. The content for the final presentation involves a brief review of the process that is being improved, the analyses performed on the current process, recommended countermeasures to the current process, the impact of those process changes, and a plan for implementation. The format is required to be in A3. Final presentations are to be kept under 30 minutes, and dependent on company managers regarding on-site presentations or voiced over PowerPoints sent online.

The presentations are graded on the following criteria:

- Quality of PowerPoint or Prezi slides (client preference)

- Correct level of detail per the A3 problem-solving format (Figure 1)

- Participation of all group members (group member evaluations)

- Speaking quality (eye contact, projection, understanding content)

- Time management

\subsection{Project Components}

Each team must submit components in association to their final project and final grade:

- Project proposal

- Steps 0-10 of the A3 framework in PowerPoint/Prezi voiced over slides

- Project plan for implementation (times and resources)

- Evaluations of the other group members (3 total for the semester)

- Executive summary for the team

- The A3 diagram of the project

The detail among these components works alongside the grading style for the instructor, as each group member must show the depth in their understanding of lean management in each component.

\subsection{Project Management Process}

Chapters 1 though 5 of the course text, The McKinsey Mind, summarizes the A3 
approach to problem-solving and the benefits associated with this framework (Sroufe \& Ramos, 2011; Sroufe \& Ramos, 2015). Chapters 6 and 7 offer additional insight to managing the team, your client, and yourself. Table 6 shows the steps that are required to manage projects effectively. Students are expected to be well-rounded in the categories of Table 6.

Table 6. Managing projects effectively.

Steps:
1. Frame the Problem
a) Analyze the client's situation and needs
b) Identify the key issues
c) Determine problem(s) to solve for why

\section{Develop/Screen Hypothesis}

a) Articulate idealized state by brainstorming the possibilities

b) Define any project boundaries

\section{Design the Analysis}

a) Determine information needed to prove/disprove hypotheses

b) Structure analysis; select appropriate tools

\section{Gather "Smart" Data}

a) Develop/test questionnaires and protocols; conduct interviews

b) Collect useful information quickly (per advice from text, faculty, and client)

\section{Interpret the Results}
a) Find the "so what" insight to assess the risks
b) Draw conclusions
c) Generate solutions (per client capabilities)
d) Forecast impact of change

\section{Present Your Ideas}

a) Develop team strategy for convincing clients that change is merited and achievable

b) Prepare deliverables to specifications

\section{Milestones:}

- Agreement on scope, goals, measurements, and exclusions from project charter

- Documentation of "as is" model and practices

- Presentation of logic tree and organizing frameworks

- Understand/acknowledgement of constraints

- Working agreement on which possibilities align with mission and values

- “QDT” analysis (See chapter 1)

- Refined scope document

- Work plan - tasks, duties, timetable - aligned to "big picture" client and culture

- Identification of key drivers/factors that have major impact on problem(s)

- Knowledge Management (KM) documents

- Share/discuss with entire team

- "Pre-wire" instructors

- Get timely "reaction" from client (go/no go)

- Gap analysis

- Financial analysis

- Analysis and forecasts using proven models and tools

- Opportunity matrix - short and long term

- Recommendations and action plans that are "pre-wired" with faculty and primary client stakeholders

- Written strategic plan that outlines a significant change from management recommendation, including implementation guidelines, timetable, and budget

- PowerPoint slides for final presentation

\section{Company X: A Case Study Example}

Local to WMU's campus, Company $\mathrm{X}$ is a manufacturing plant of a globally diversified management and holding company that keeps a focus on lean enterprise. Teaming up with faculty from WMU, this company's mission and values 
align perfectly with the design of the applied six sigma course. While Company $\mathrm{X}$ pushes their employees to utilize the "why" questions, daily metrics, communication, and root cause analysis identification, they assure WMU's ISM staff that they will be holding MGMT 3810 students to the same standard.

Reflecting on the most recent contributions to Company X, students used the A3 process to increase the efficiency of assembly for a newly introduced product line and organized the visual presentation of inventory data involved in the company's production planning schedule. With a few barriers of inventory shortage and allocation of labor, the team members introduced visual elements into the product line's workspace for training and reference purposes to provide the department with a better and faster goal of assembly. Interactive visuals on Excel were established to condense data that is imported from their ERP system to the job scheduling department for analysis. Using templates provided by the leaders at Company $\mathrm{X}$, the students observed, recorded, and documented the operating procedures for the new product's assembly to develop flow charts and standardized work instructions. Consolidation and manipulation of data overflow for job schedulers allowed the students to filter a system in organizing the release of jobs for each operation throughout the facility. These solutions contribute to the orientation and training of employees, as well as the interpretation and application of job scheduling throughout a company that strives for short lead times and upholds a culture of waste elimination.

\section{Conclusions}

The combination of strategic thinking and hands-on experience with professional evaluation sets WMU graduates up for industry preparedness. The ISM program mantra is "ready day one" and the results from business partners from the applied six sigma course confirm that these students have what it takes to keep up with industry variation. Over the recovery phase of COVID-19, the supply chains are receiving global attention and the versatility required for staying above water, and to do so competitively, involve the collective skills of critical thinking, communication, teamwork, and creative innovation.

Recruiters of supply chain professionals are consistently pleased with the results produced from WMU's ISM program. These graduates are entering the field prepared to analyze operations and make decisions that will improve various areas of the supply chain simultaneously. Understanding and implementing aspects of lean management are important in the WMU ISM curriculum and practicing real time with such successful organizations instills confidence in the level of pride that comes with being a WMU graduate. With professional experience, graduates obtain the ability to communicate in different ways with a range of directors and teammates, providing advantages in the hiring process. Continuous improvement execution encourages great minds to go farther, and the profession-ready talent that emerges from the Western Michigan University Integrated Supply Management program benefits the industry by delivering in- 
novative individuals that are ready shape the supply chains of tomorrow.

\section{Conflicts of Interest}

The authors declare no conflicts of interest regarding the publication of this paper.

\section{References}

AMA Staff (2019, January 24). AMA Critical Skills Survey: Workers Need Higher Level Skills to succeed in the 21 st Century.

https://www.amanet.org/articles/ama-critical-skills-survey-workers-need-higher-levelskills-to-succeed-in-the-21st-century/

Apple, R. (2021, July 8). Reasons for the Supply Chain Talent Shortage \& How Are Companies Adapting. Supply Chain Careers https://supplychaincareers.com/supply-chain-talent-shortage/

Business Performance (2014). Why Communication Practices Are Important in the Workplace. Optum.

https://intranet.ecu.edu.au/ data/assets/pdf file/0019/501634/Communication-practi ces-for-managers-Jan15.pdf

Chumakov, C., \& Stiffler, D. (2020, June 29). Top 25 North American Supply Chain Undergraduate University Programs, 2020. Gartner.

https:/emtemp.gcom.cloud/ngw/globalassets/en/doc/documents/729916-top-25-north -american-supply-chain-undergraduate-university-programs-2020.pdf

Field, A. (2012, November 30). 6 Ways to Foster Collaboration in Your Workplace. American Express.

https://www.americanexpress.com/en-us/business/trends-and-insights/articles/fosterin g-collaboration/

Flaherty, C. (2021, April 6). What Employers Want.

https://www.insidehighered.com/news/2021/04/06/aacu-survey-finds-employers-wantcandidates-liberal-arts-skills-cite-preparedness

Fry, R. (2020, November 9). The Pace of Boomer Retirements Has Accelerated in the Past Year. Pew Research Center.

Gartner. (n.d.). Gartner Acquisitions: Gartner Acquires Software Advice. Gartner. https://www.gartner.com/en/about/acquisitions/history/software-advice-acquisition

Grand View Research (2021, July). Supply Chain Analytics Market Share Report 2021-2028.

Hicks Terry, K. (2015, August 31). The Importance of Collaboration. University of Georgia Small Business Development Center.

https://www.georgiasbdc.org/terry-the-importance-of-collaboration/

Institute for Supply Management (2021, September 1). Manufacturing $P M I^{\circledast}$ at 59.9\%; August 2021 Manufacturing ISM ${ }^{\circledast}$ Report On Business ${ }^{\oplus}$.

https://www.prnewswire.com/news-releases/manufacturing-pmi-at-59-9-august-2021manufacturing-ism-report-on-business-301366785.html

Jones, A. (2019, January 20). WMU Supply Chain Program Ranked Second in Nation by Tech Research Firm. Mlive.

https://www.mlive.com/business/west-michigan/2015/02/wmu supply chain_program ranke.html

Panigrahy, N. P., \& Kumar Pradhan, R. (2015, March). Creativity and Innovation: Exploring the Role of HR Practices at Workplace. In National Conference held at Ravenshaw Business School (pp. 1-17). 
https://www.researchgate.net/profile/N-P-Panigrahy/publication/305924360 Creativity and Innovation Exploring the Role of HR Practices At Workplace/links/57c86bf 308aec24de044f35e/Creativity-and-Innovation-Exploring-the-Role-of-HR-Practices-At -Workplace.pdf

Prince, T. (2020, April 2). Word of the Year: Supply Chain. Word of the Year: Supply Chain.

https://cloudfront.drupal.prod.joc.com/international-logistics/word-year-supply-chain 20200402.html

Rubrich, L. (2010, February 22). A3 Problem Solving: What It Is... and What It Isn't. Reliable Plant. https://www.reliableplant.com/Read/22984/a3-problem-solving-lean

Sroufe, R., \& Ramos, D. (2011). MBA program trends and Best Practices in Teaching Sustainability: Live Project Courses. Decision Sciences Journal of Innovative Education, 9, 349-369. https://doi.org/10.1111/j.1540-4609.2011.00315.x

Sroufe, R., \& Ramos, D. P. (2015). Leveraging Collaborative, Thematic Problem-Based Learning to Integrate Curricula. Decision Sciences Journal of Innovative Education, 13, 151-176. https://doi.org/10.1111/dsji.12063

Talbert, M. (2020, September 2). Supply Chain Salary and Career Report Reveals Rewarding Jobs and Opportunities. ASCM Insights.

https://www.ascm.org/ascm-insights/supply-chain-salary-and-career-report-reveals-re warding-jobs-and-opportunities/

Technologies, S. (2021, January 13). Growing Supply Chain Competitive Advantage among Transportation \& Logistics Professionals. Supply Chain 24/7. https://www.supplychain247.com/article/growing supply chain competitive advantag e

U.S. Bureau of Labor Statistics. (2013, December 1). Projected Changes in the Labor Force. U.S. Bureau of Labor Statistics.

University of the People (2021, December 9). The Importance of Critical Thinking, and How to Improve It.

https://www.uopeople.edu/blog/why-is-critical-thinking-important/

Urban, E., \& Miller, L. (2021). Post-Graduation Activity Report 2019-2020 (pp. 143). Western Michigan University.

Watson, R. (2017, January 27). College Ranks no. 2 in World for Supply Chain Program. Grand Rapids Business Journal.

https://grbj.com/news/college-ranks-no-2-in-world-for-supply-chain-program/

Wilkie, D. (2020, February 28). Employers Say Students Aren't Learning Soft Skills in College. SHRM.

https://www.shrm.org/resourcesandtools/hr-topics/employee-relations/pages/employer s-say-students-arent-learning-soft-skills-in-college.aspx 